\title{
Oil and Gas Rents and Civilian Violence in the Middle East and North Africa, 1990-2004: A Resource Curse, or Rentier Peace?
}

\author{
Matthew Costello \\ Criminology, Sociology, and Geography Department, Arkansas State University, Jonesboro, AR 72401, USA; \\ mcostello@astate.edu
}

Received: 27 December 2017; Accepted: 2 March 2018; Published: 8 March 2018

\begin{abstract}
Acts of civilian violence have long plagued parts of the Middle East/North Africa (MENA) region. Extant research debates whether countries that rely on natural resource revenue for economic solvency are more or less likely to experience such violent events. This analysis takes a novel approach to this issue, examining the unique effects of publicly and privately controlled oil and gas rents on civilian violence in the MENA region from 1990 to 2004. Data on civil violence events are drawn from the World Handbook of Political Indicators IV. Results indicate that publicly owned oil and gas rents reduce civilian violence, while privately owned oil and gas rents do not significantly affect such events. This lends support to the notion that oil and gas rents are not necessarily a curse, and can actually foster a "rentier peace." More broadly, these results underscore the importance of delineating ownership structure when examining the relationship between natural resources and conflict.
\end{abstract}

Keywords: conflict; civil violence; resource curse; rentier peace

\section{Introduction}

A surfeit of research explores the relationship between natural resources and violent conflict. The nature of the relationship is still roundly disputed, however. Some researchers, for instance, find that natural resources instigate or prolong internal violent conflict (Collier and Hoeffler 1998, 2004; Fearon and Laitin 2003; Hegre and Sambanis 2006; Lujala 2010; Ross 2006), while others find that natural resources reduce the likelihood of conflict (Costello 2017; Basedau and Lay 2009; Brunnschweiler and Bulte 2009; Smith 2004). Still other scholars note that the relationship is conditioned on a host of factors, including the kind of conflict at issue or the type and location of natural resources within a given country (Lujala 2009, 2010; Sorens 2011). To complicate matters further, some research reports previously established relationships between natural resources and conflict are simply the product of spurious correlations (Brunnschweiler and Bulte 2008; Thies 2010).

This study engages the aforementioned debate by exploring whether oil and natural gas rents affect civil violence events in the Middle East and North Africa (MENA) from 1990 to 2004. I focus on the MENA region for a few reasons. For one, the Arab Gulf stands as the world's largest single regional source of crude oil (Jenkins et al. 2011), rendering it an ideal test case for the examination of the effect of oil and gas rents on conflict. Additionally, conflict is unusually high in the MENA region, relative to other parts of the world. The Israel-Palestine dispute has endured for more than half a century, with no apparent resolution in sight. Moreover, Iraq has hosted two of the largest international wars since 1990, while the Iran-Iraq war was one of the bloodiest inter-state wars of the past several decades. The Arab Awakening, fraught with bouts of citizen protests and state-sanctioned violence, is one of the latest examples of violence. As the uprisings rippled throughout Tunisia, Egypt, Libya, Yemen, Syria, and beyond, preconceived notions about the "culture of violence" in the Middle East were reinforced on television screens and in newspapers around the world. 
Accepting the premise that conflict is endemic in the MENA region begs the question of why. Familiar explanations point to the rampant political repression and economic stagnation throughout the region. Still others evoke cultural explanations, attributing conflict to the "violent nature" of Islam and a value system that lionizes martyrdom. In this paper, I examine political, social, and economic factors that might help explain civil violence in the MENA region, although I pay particular heed to the effect of oil and gas rents on such events. More specifically, I examine whether publicly and privately controlled oil and gas rents uniquely affect civil violence in the region. This distinction in ownership structure has generally been overlooked in the present literature on natural resources and conflict (for exceptions, see Costello 2017; Jones Luong and Weinthal 2010; Weinthal and Luong 2006), rendering knowledge on the topic incomplete. Jones Luong and Weinthal (2010), however, argue that the potential benefit or hindrance of oil hinges largely on who owns the corresponding revenue. They contend that oil industry privatization, which is becoming increasingly common (Jones Luong and Weinthal 2010; Weinthal and Luong 2006; McPherson 2003; Warshaw 2012; Tordo and Tracy 2012), may mitigate many of the adverse outcomes, including economic stagnation, repression, and violence, commonly associated with state-controlled resource wealth.

In addition to accounting for the ownership structure of oil and gas industries, this analysis takes a unique approach by focusing on civil violence, a small-scale form of conflict. Similar studies on the effects of natural resources overwhelmingly examine either the onset or duration of civil wars, which are larger, bloodier, and rarer than civil violence events. The paucity of civil wars means that there is an inherent problem with overdetermination when they are used as a dependent variable. Their rarity makes it difficult to isolate the effects of natural resources on their occurrence. Koubi et al. (2014) have therefore called on researchers to examine the association between natural resources and a diversity of conflict outcomes. This paper seeks to answer that call by focusing on civil violence events and their potential association with publicly and privately-controlled oil and gas rents. Specifically, I investigate two primary research questions in this paper:

Research Question \#1: Do oil and gas rents affect civil violence events in the MENA region during 1990-2004?

Research Question \#2: Do publicly controlled oil and gas rents and privately controlled oil and gas rents uniquely affect civil violence events in the MENA region during 1990-2004?

\section{Natural Resources and Violent Conflict: Resource Curse or Rentier Peace?}

Are natural resources a curse? The answer to this question has proven elusive. Logically, natural resource wealth should serve as an economic boon; often this is not the case, though. In fact, recent history is fraught with examples of resource-rich countries beset with corruption, repression, and violent conflict.

The oft-observed positive association between natural resources and conflict is frequently attributed to the effect resource revenue has on governing bodies. Governments in resource-rich countries often rely on external rents, not citizen taxation, for economic viability (Chaudhry 1997; Karl 1997). They do so for politically expedient reasons-namely, establishing a bureaucratic tax-collecting system is difficult, and lowering taxes is generally popular. Similarly, resource wealth can hinder the development of an effective governing class (Fearon and Laitin 2003). Leaders in resource-rich countries often make the political calculation that building robust institutions that foster democracy and economic growth is not in their best interest (Isham et al. 2003). Doing so can undercut their drive to consolidate power because bureaucracies demand a measure of transparency and accountability (Auty 2001). The lack of tax revenue and an effective ruling class in resource-abundant nations can lead to institutional fragility, leaving them vulnerable to rebel challenges. As Humphreys (2005) explains, an untaxed citizenry has fewer levers at their disposal to bend the government to their collective will. In turn, the autonomy of rent-seeking governments can lead to festering discontent, and, at times, violence. 
Other research emphasizes how insurgent groups can be spurred into violent action by the presence of natural resources. For instance, when resource wealth is sequestered in the hands of the ruling class the value of capturing the state increases. Consequently, this can incentivize civilian-led violence (De Soysa 2002; Fearon and Laitin 2003; Le Billon 2005). Conversely, when natural resources are located in an ethnically-marginalized region of a country, rebels might elect to seek independence in pursuit of sole control of the resources. "Lootable" natural resources can also be used by dissidents to finance their rebellion (Collier and Hoefflery 2004; Le Billon 2001). Short of looting the resources, violent civil actors can extort money from natural resource companies that operate in their territory (Collier et al. 2009; Dal Bó and Bó 2011; Ross 2012).

Further explanations linking natural resources to conflict purports that resources can induce a host of grievance that ultimately manifest in violence (Ross 2003, 2004, 2012). For instance, non-resource segments of a country's economy can suffer when natural resources dominate (The Economist 2005), in turn leading to poor living standards. Alternatively, sharp economic downturns can occur in oil states, which are particularly susceptible to price shocks as the price of oil fluctuates on the world market (Humphreys 2005). Oil states are also frequently plagued by higher-than-average rates of unemployment, particularly in parts of the MENA region where foreign workers are preferred to local labor in the oil industry (Ross 2012). The process of natural resource extraction or the mal-distribution of resource revenue can likewise foster citizen discontent, or even violence (Fearon 2005; Fearon and Laitin 2003; Humphreys 2005; Ross 2004, 2006, 2012; Thies 2007).

It is critical to recognize, however, that not all research finds a positive link between natural resources and conflict. While the dominant view in the literature undoubtedly skews towards a "resource curse" orientation, contrary work that speaks to the possibility of a "rentier peace" (Luciani 1987; Mahdavy 1970) exists as well. Fjelde and De Soysa (2009) deftly outline the key tenets of this position, discussing how resource revenue can be harnessed to build state capacity, coerce or co-opt opposition, or simply goad would-be rebels into cooperating with the ruling regime.

Coercive force, usually in the form of military might or state police, can be used by governments to quash internal dissent (Cotet and Tsui 2013; Le Billon and Kathib 2004). Boulding (1989) contends that the threat of state power and fear of government retaliation for defection often facilitate peace. As Fearon and Laitin (2003) note, a state's military and policing apparatus is key to monitoring, deterring, and suppressing any potential dissent. Resource wealth can be utilized to strengthen a country's coercive capacity, especially if the resources are lucrative.

Coercion is not the only mechanism at the state's disposal to generate civilian compliance; governments can also co-opt political opposition forces (Fjelde 2009). This can be accomplished through spending on public goods, like education and healthcare (Levi 2006), or other economic transfers (Heydemann 2004; Azam 1995, 2001; Gandhi and Przeworski 2006). This perspective is in line with Boulding (1989) concept of economic power, which states that compliance can be won by offering adversaries something that they value in return. Resource wealth can be and often is used to erect robust social safety nets and facilitate wealth transfers.

Finally, citizen compliance can be acquired through cooperation. Cooperation necessitates trust-namely, citizen must trust that state institutions will uphold the social contract that bonds the governing class to the people (Olson 2000; Levi 2006). When people trust their government to effectively and fairly regulate social exchange and exercise authority equitably, coercion or co-optation are less necessary. North et al. (2000) argue that political order involves state capacity related to the creation of commitments that the populace trusts. Resource wealth can be used to build such capacity, thereby fostering stability and a lack of violent civilian unrest.

\section{Why Ownership Structure Matters}

The preceding discussion outlines various explanations linking natural resources to violent conflict. Largely absent from the prevailing dialogue, though, is a recognition that who controls natural resource revenue likely patterns its effect on conflict. Indeed, nearly all extant studies on the "resource 
curse" necessarily presume that resource wealth is owned and controlled by the state. Of course, this is not true. If theories of resource-induced conflict are accurate, then who owns the resource revenue should matter. Past studies have been hampered by the unavailability of reliable data to test the effect of natural resource ownership. This is starting to change, however. Jones Luong and Weinthal (2010), in their seminal work "Oil is Not a Curse: Ownership Structure and Institutions in Soviet Successor States," argue that oil-abundant states are not destined to poor economic outcomes, lagging and uneven economic growth, authoritarianism, and weak institutions. Rather, the potential for a state to be beset with such problems largely hinges on who owns the oil wealth-the state or private entities. Similarly, recent work demonstrates that the ownership structure of natural resources is an important factor in predicting domestic terror events (Costello 2017) and the initiation of international crises (Bakaki 2016).

The leading theories linking natural resources to conflict contend that resources in the hands of the state can lead to weak state institutions, induce grievances on the part of the citizenry, allow regimes to exert force through repression, or represent a prize for dissidents. All of these theories, of course, rely on the premise that natural resource revenue flows to the state. Hence, the ownership structure of natural resources should be a key factor in determining their effect on violent conflict (see Costello 2017; Jones Luong and Weinthal 2010; Weinthal and Luong 2006).

For instance, a common argument is that an over-reliance on external revenue fosters weak institutions, a lack of democratic ideals, and lagging economic growth (see, e.g., Isham et al. 2003, Karl 1997). Rents are said to create a disincentive for the state to invest in robust institutions and a diversified economy. Rather, a preference for the status quo is favored over the arduous task of offering sound, responsible governance and effective bureaucratic apparatuses (e.g., Anderson 1987; Beblawi and Luciani 1987; Chaudhry 1989; Karl 1997; Mahdavy 1970). Ross (2001) goes as far as arguing that some regimes will even weaken existing institutions in an attempt to restrict the use of rent windfalls beyond the parameters of the state. However, we should not expect these same weak-state outcomes if resource revenue is controlled largely by private entities. Indeed, Weinthal and Luong (2006) argue that countries with privately controlled resource revenue have business-state relations that are clear and balanced. Such arrangements promote mutual incentive to construct stable institutions that help ensure fiscal predictability, thereby reducing internal violence resultant of weak institutions, according to the authors.

Alternatively, if natural resource revenue cultivates stability, this effect should be magnified when the state controls resource revenue since direct ownership generates more revenue than taxing private entities (Wegenast 2016; Mahdavi 2011; Andersen and Ross 2012; Ross 2012; Mommer 2002; (Friedman 2006; Guriev et al. 2011). Ross (2001) argues that governments can use oil and mineral windfalls to construct repressive forces that ward off opposition forces and maintain their stranglehold on power. He finds that oil wealth is correlated with military spending, which can allow for authoritarian rule. Bellin (2002) comes to a similar conclusion, focusing on Muslim-majority countries. We should not expect, however, privately controlled resource revenue to be used in a similarly repressive manner. Additionally, it is unlikely that private corporations would be interested in using resource revenue to co-opt or otherwise pacify opposition forces, although a state might be inclined to do so.

In sum, there is growing recognition that the prevailing notions of an "oil curse" or "rentier peace" rely on a faulty proposition - that natural resource wealth is always controlled by the state. It is only recently that researchers have started to challenge this notion, resulting in important insights into resource ownership and state-level outcomes, including violence. By separately examining publicly and privately controlled oil and gas rents in this analysis, I can more precisely examine the relationship between natural resources and conflict. Doing so is paramount for developing a clearer understanding of whether-and under what circumstances—natural resources are a curse or blessing. The subsequent section offers detail on how I explore this matter. 


\section{Methods and Data}

I examine a sample of eighteen countries in the MENA region for the period 1990-2004 to assess the effects of publicly and privately owned oil and natural rents on civil violence events. Due to missing data issues on some of the independent variables, the sample size ranges from 205 to 177 observations, depending on the model. I employ a pooled cross-sectional time-series regression with a negative binomial model (Cameron and Trivedi 1998) applied to the annual country count of civil violence events for this analysis. Negative binomial regression is a form of Poisson regression that corrects for overdispersion. Overdispersion is a common problem with count data where zero is the smallest value and counts range upward. In such instances, including this one, ordinary least squares regression is not preferable. The dependent measure in this analysis is overdispersed, and the use of a negative binomial adjustment adds a stochastic component to the model (Land et al. 1996).

Panel data have the problem that units are not truly independent, violating a central assumption of OLS. This can be corrected using fixed or random effects. Fixed effects has the drawback that unit constants cannot be included. Random effects is designed to overcome two limitations of fixed effects. First, by not including dummy variables for each case, random effects saves on degrees of freedom. This provides a more efficient estimator of the coefficients than does fixed effects. Second, random effects can estimate the coefficients on time-invariant variables (i.e., monarchical regimes) (Johnston and Dinardo 1997).

Serial autocorrelation is always a concern with panel data. Serial autocorrelation can bias the standard errors, leading to a model that is less efficient (Drukker 2003). To test for serial autocorrelation, I use the Woodridge Test, which is appropriate for random effects models. Because the Wooldridge test makes fewer assumptions than other tests of serial autocorrelation, it tends to be more robust. The Wooldridge Test indicates the absence of first-order serial autocorrelation in the data when applied to the baseline model for this analysis $(\mathrm{F}=0.540 ; p=0.4757)$. This is indicated by failing to reject the null hypothesis of no serial autocorrelation. Independent variables are lagged one year throughout to create temporal order.

\subsection{Dependent Variable}

The dependent variable for this analysis is the number of civil violence events per country annually. The data are drawn from The World Handbook of Political Indicators IV (Jenkins et al. 2012). This dataset offers a series of country-level indicators of contentious politics events. The architects of the data define "contentious politics" as attempts to bring about or resist political change using actions that are outside of the bounds of routine politics and entail uncertainty and negative sanction. The World Handbook IV dataset is a subset of the larger Integrated Data for Event Analysis (IDEA) event framework.

My unit of analysis is described as an armed or violent attack by sub-state civilian actors as reported in Reuters newswire and Agence France Presse. I utilize the WHIV annual file, which involves attempts to bring about or resist political change using armed and/or coercive actions against the state or other political actors. Civil violence includes abductions, such as hijackings or kidnappings, physical assaults, armed attacks, which span the spectrum from small arms attacks, bombings, artillery attacks to coups, and attacks utilizing unconventional forms of violence, such as biological or chemical weapons. These various event forms are added together, providing an annual count of civil violence for each country in the MENA region contained in the WHIV.

A key consideration with count data is the potential for selection bias. Researchers examining country-level event data over a long time-series have few options for collecting data. Newswire reports are generally the best option due to their frequency, access, relative lack of selectivity, consistent reportage structure, continuity over time, and ease of coding. Newswires are more complete than traditional newspapers, because of their $24 / 7$ operations and frequency of reportage. They also tend to report accurately to maintain their reputation. Even so, I cannot say with certainty that selection bias does not exist in my dependent variable. To partially combat this, I control for the level of press 
freedom. This addresses the likelihood that repressive regimes restrict certain stories and thereby bias coverage.

Civil violence events are skewed with a country-year mean of 19.97 and standard deviation of 75.07. While many of the countries in the dataset encounter zero or one civil violence events in a given year, others suffer greatly. The skewness is largely driven by one country year, Iraq in 2004. Iraq experienced 1125 civil violence events in 2004, a four-hundred percent increase from the previous year. This figure dwarfs all other country-year figures in the region. However, it does not appear that the inclusion of this outlier case affects the results of this analysis. To verify, I ran separate analyses ${ }^{1}$ that first excluded this one case, and then excluded the year 2004 entirely. In both instances, the results were nearly identical.

Figures 1-3 display trends in annual civil violence events per capita for countries in the MENA region for the years 1990-2004. Countries are categorized as belonging to the "Fertile Crescent," "Arab Gulf," or "North Africa" regions. ${ }^{2}$ The number of civil violence events in the Arab Gulf region, displayed in Figure 1, fluctuate greatly between countries and over time. Bahrain and Qatar, two relatively small countries, register some of the highest per capita counts in the region. Events in Kuwait are also relatively high, although several years of data are missing. Civil violence events per capita are low in Oman and Yemen, as well as Saudi Arabia and the U.A.E. The latter two countries experience spikes in 2004, however.

Figure 2 demonstrates that Algeria and Tunisia experienced some of the highest counts per capita in the North Africa region. The number of events per capita in Libya, Mauritania, Morocco, and Sudan remain low throughout the entire period. In fact, only Libya and Sudan experience more than one event per capita per year in a few of the years analyzed. Figure 3 demonstrates that parts of the Fertile Crescent region are more volatile. The most obvious trends are the spike in events in Iraq in 2003 and 2004, and the large number of events in Lebanon, especially in the early-to-mid 1990s. Much of the violence in Lebanon followed a long civil war, and the surge in Iraq corresponds to the U.S.-led invasion in 2003. Egypt and Jordan also experienced relatively high per capita counts in particular years, whereas Syrian events of civil violence per capita never surpass one per year.

Results of the separate analyses are available upon request.

It is important to note that the $y$-axis scale is different for the line graph displaying the Fertile Crescent countries. This is because Lebanon and Iraq experienced civil violence events per capita significantly higher than any other countries in the Arab Gulf or North Africa regions. To make the scales equivalent for all three regions would render the graphs for the Arab Gulf and North Africa nearly unreadable. 


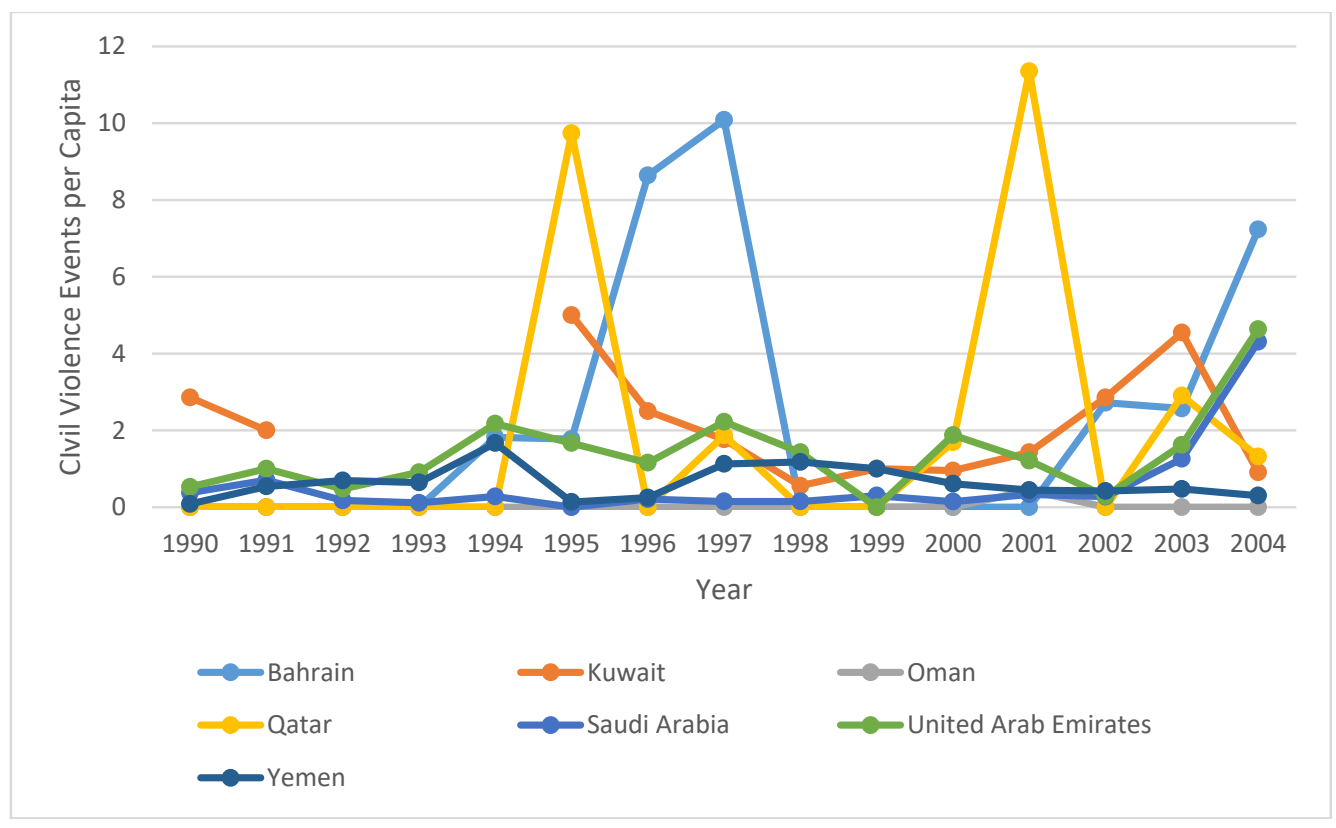

Figure 1. Civil Violence Events per Capita: Arab Gulf, 1990-2004.

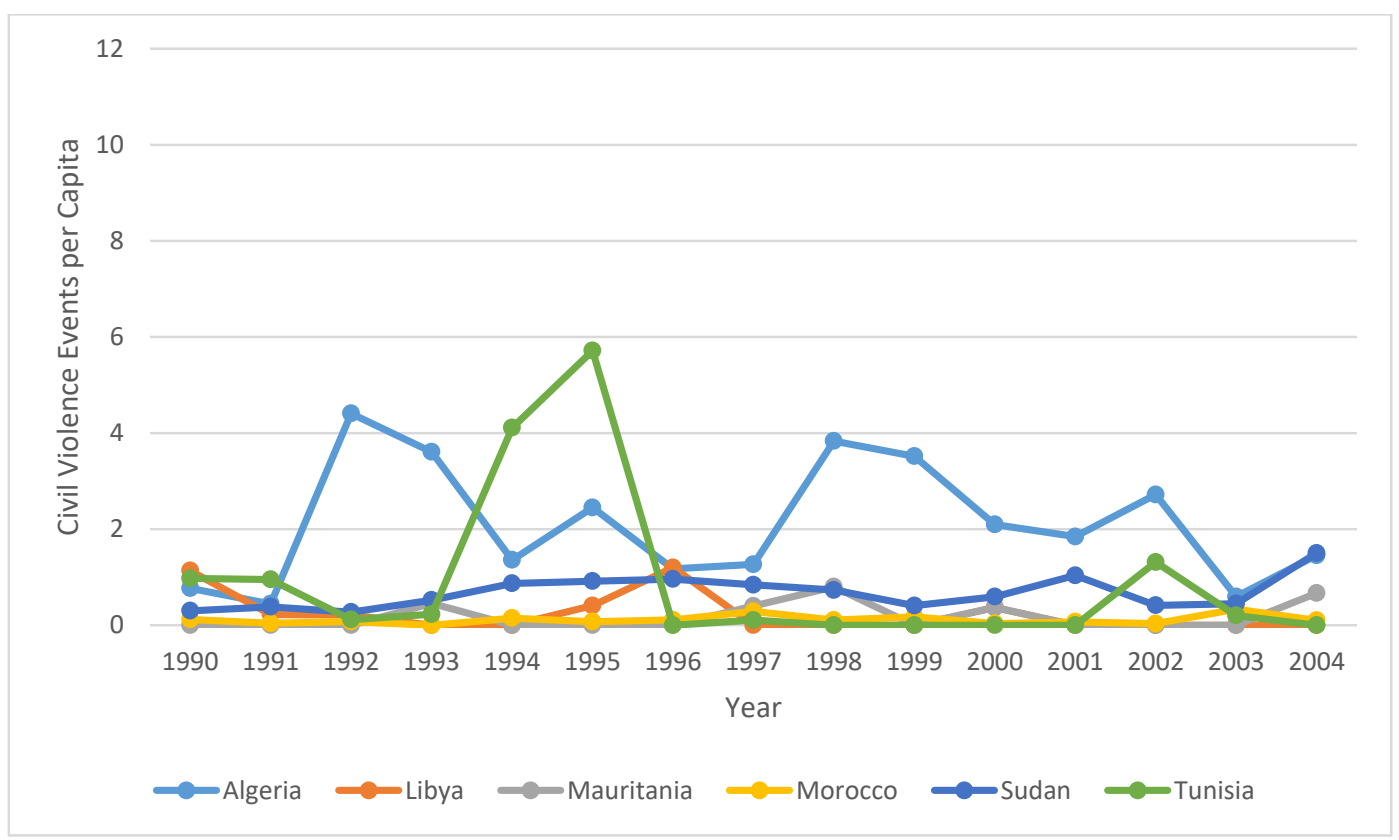

Figure 2. Civil Violence Events per Capita: North Africa, 1990-2004. 


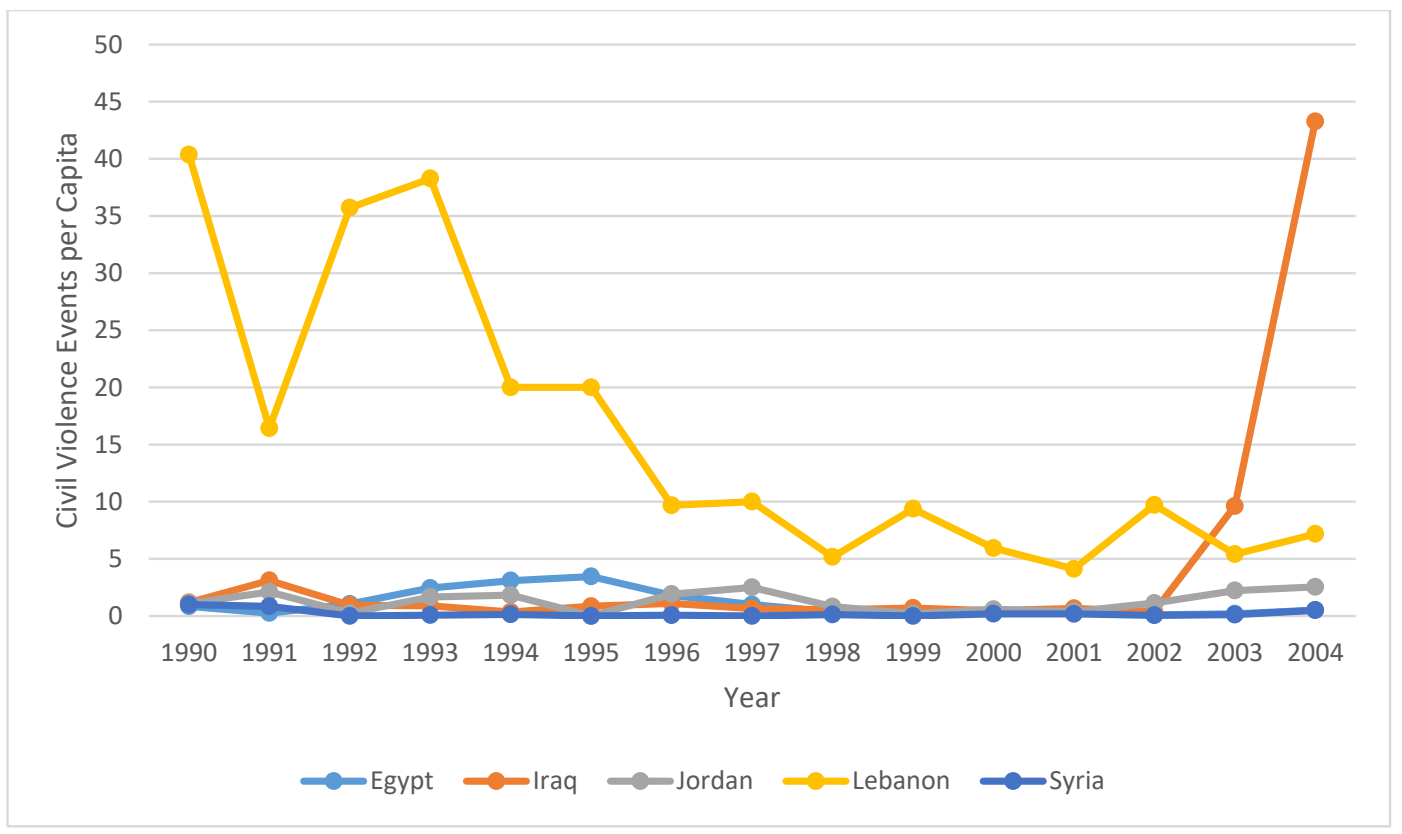

Figure 3. Civil Violence Events per Capita: Fertile Crescent, 1990-2004.

\subsection{Independent Variables}

\subsubsection{Oil and Natural Gas Rents}

This study is motivated by the desire to understand the effect of oil and gas revenue on civil violence events in the MENA region. An important initial question is how best to measure oil and gas. Some researchers use exports as a percentage of GDP (Collier and Hoeffler 1998; Fearon 2005). Since oil and gas states extract revenue from the international sale of oil, it is argued that exports best approximate dependency (Costello 2017; Costello et al. 2015). Alternatively, oil and gas revenue per capita is also commonly used (Ross 2012). This approach approximates abundance, not necessarily dependency (Karl 1997). A third metric, and the one I elect to use, captures oil and gas rents as a percentage of GDP. Rent measures approximate the role of rents relative to the size of a country's economy (World Bank 2015). The World Bank operationalizes oil and gas rents as the difference between the value of crude oil and gas production at world prices and the total costs of production. This measure is constructed by estimating the world price of units of oil and gas and subtracting estimates of average unit costs of extraction and harvesting costs, which includes a normal return on capital. The unit rents are then multiplied by the physical quantities of oil that countries extract to determine the rents as a share of GDP. The use of this measure recognizes that oil and gas are unique commodities whose production costs are typically a small share of the total revenues earned from its sale. Rents afford the state the luxury of foregoing bureaucracy-building and seeking policies that promote economic growth by offering a source of revenue that is largely independent of the citizenry (Karl 1997; Barma et al. 2012; Tordo and Tracy 2012).

I utilize three measures of oil and gas rents in this analysis. All three are logged to correct for skewness. One measure does not distinguish ownership structure, while the other two split oil and gas rents into categories based on public or private ownership. This approach allows ownership to be treated as a variable, not a constant. Weinthal and Luong (2006) argue that, for many social and political performance issues, the central question is the independent effects of state and private ownership of mineral resources, not resource wealth, per se. State ownership of oil and gas rents should have systematic consequences for the administrative capacities and economic, military, and social policies of these states which will make them more or less vulnerable to internal violence. 
The measure of public and private oil and gas ownership used in this study builds off of a metric constructed by Jones Luong and Weinthal (2010, Appendix B, pp. 345-9). They identified the dominant country strategy for the oil industry in many of the largest oil producing countries for 1970 to 2010. They make a refined distinction between state ownership with control and state ownership without control, but this is secondary to the main question of whether royalties are largely controlled by the state or remain principally private. I therefore treat their measure dichotomously, distinguishing between countries with a state owned oil production sector or a privately owned oil production sector. I supplement Jones Luong and Weinthal (2010) coding with a comprehensive search for evidence of state or private ownership of oil and gas industries in additional oil and gas producing nations. Information on the ownership structure of these industries was available from the Center for Energy Economics (2008), The World Bank Groups' A Citizens' Guide to National Oil Companies, Part B Data Directory (World Bank 2008), McPherson (2003) World Bank report, National Oil Companies: Evolution, Issues, Outlook as well as research complied by Tordo (2011) and Tordo and Tracy (2012) in the World Bank Report on National Oil Companies. In many cases, information on shareholdings was readily available. In such instances, countries were coded as publicly owned industries if the state held the majority of shares in production, refining, and/or exporting facilities. Shareholding information was not available for all states, though. If, however, the language of the source made it clear that the state was the dominant actor in the oil and gas business, they were coded as publicly owned. The same logic, reversed of course, was utilized to code private ownership. Ambiguous cases where the primary actor in the oil and gas industry could not be reasonably determined were not coded.

\subsubsection{Control Variables}

The following set of variables appear in all models. They serve as the baseline model for this analysis. A measure of GDP per capita is included to assess the overall health of a country's economy. This measure is drawn from the World Bank (2015). I expect higher GDP per capita to be associated with general citizen contentedness and therefore fewer civil violence events.

Price spikes in food and other basic consumer goods can also lead to citizen discontent. Many countries in the MENA region are highly dependent on imported food, and hence are hit particularly hard when global food prices escalate. I use the annual consumer price index (CPI) to tap this increase in basic consumer goods prices (World Bank 2015). The average annual CPI is 124 $(2005=100)$, ranging from 95 to 204. I expect increases in the CPI to result in higher incidences of civil violence.

Logged population estimates, drawn from the World Bank (2015), are included in part because the dependent variable is counts. Including population estimates controls for the possibility that larger populations are simply likelier to suffer more civil violence events because recruits are more abundant. Additionally, it serves as a rough proxy for strain associated with rapid growth.

A measure of the share of young people in a population is included because a substantial "youth bulge" can present countries with an economic challenge. The youth bulge is gauged as the share of youths and young adults between the ages of 15 and 24 relative to the adult population. I draw population estimates from the United Nations Population Division (2012) population age estimates. I expect countries with a larger youth bulge to suffer disproportionately from civil violence. Unemployed or under-employed young people might be especially likely to engage in civil violence.

Ethnic group fractionalization is assessed using a measure developed by Cederman et al. (2010). Ethnic group fractionalization scores range between 0 and 1, with higher scores indicating more fractionalization. This measure is included because ethnic fractionalization has been shown to be an important predictor of low-intensity conflict (Hegre and Sambanis 2006; Buhaug 2006).

A dummy measure is used to capture regime type. A " 1 " corresponds to a country that is a monarchy, and a " 0 " corresponds to countries with other regimes. Most of the monarchies in the MENA region are oil states, prompting a debate regarding whether civil violence in monarchies is a result of their government structure of their oil and gas wealth. I expect monarchies to have lower 
levels of civil violence due in large part to their stability, but also their ability to use coercion and co-optation to quash potential violent events.

I include a measure of press freedom using Freedom House (2013) index. Press freedom is measured on a three-point scale. The original index is reverse-coded so that higher numbers represent more press freedom. The inclusion of this measure is vital because countries that restrict press freedoms are likely to be selective with regards to events that may reflect poorly on the government. As Davenport and Ball (2002) show, repressive regimes are much less likely to report terror attacks within their borders. I expect the same relationship to exist for civil violence events.

Finally, I include a dummy measure that indicates if a country is currently embroiled in a civil war. Areas subject to civil wars can serve as hospitable bases of operation for dissident groups since as governmental institutions are generally weak or lacking in conflict zones. It is therefore not uncommon for civil violence to exist alongside a civil war. The data on ongoing civil wars with a threshold of at least 1000 battle deaths in a year are derived from PRIO's Armed Conflicts Database (Gleditsch et al. 2002).

\subsection{Mediating Effects}

A debate exists concerning whether natural resource revenue leads to violence through the erosion of state infrastructure, or whether such revenue can be used to strengthen infrastructure, thereby resulting in less internal violence. I provide a test of the extent to which a range of state capacity indicators potentially mediate the relationship between oil and gas rents and civil violence.

First, I examine the potential mediating effect of state coercion using two measures-state-induced terror and state sanctions. Wood and Gibney (2010) Political Terror Scale gauges state-induced political terror. This measure integrates U.S. State Department and Amnesty International reports along with additional sources to construct a summary annual measure of political terror that ranges from 1 , indicating low levels of terror, to 5, indicating widespread and intensive terror. It assesses the level of political violence and state-induced terror, such as arbitrary arrests, imprisonment, and civilian torture at the hands of the government. I expect political terror to reduce civil violence by prompting fear in would-be violent civilian actors. However, the opposite effect could be present if greater levels of political terror undermine the legitimacy of the state, resulting in increased perceptions of political injustices that in turn lead to civil violence.

The measure of state sanctions is drawn from the World Handbook of Political Indicators IV (Jenkins et al. 2012). State sanctions are events where the government imposes restrictions or censorship on their citizens, covertly monitors them, or conducts politically-motivated arrests. I expect state sanctions to elicit higher counts of civil violence due to the likelihood that such government measures will prompt citizen grievances.

Second, two indicators of government co-optation are examined. I use a measure of general government consumption as a percentage of GDP and social spending as a percentage of GDP. Both measures are draw from the World Bank (2015). General government consumption expenditures include all government current expenditures for purchases of goods and services, including compensation of employees. It also includes most expenditures on national defense and security, while excluding government military expenditures that are part of government capital formation. Social spending combines government expenditures on education and health. I expect higher levels of general government consumption and social spending to reduce acts of civil violence. This is based on the notion that citizens will be more content, and therefore less likely to engage in civil violence, if their basic needs are met by the state.

Third, three indicators of government quality and effectiveness are used as indicators of cooperation between citizens and the state. First, government quality (Teorell et al. 2011) is measured using the mean value of three variables-corruption, law and order, and bureaucracy quality. Corruption is assessed within the political system. Law and order are assessed separately. The law component of the measure assesses the strength and impartiality of the legal system. The order component gauges popular observance of the law. Bureaucracy quality measures the institutionalize 
strength and quality of the bureaucracy. Taken together, these three sub-components comprise the measure of government quality, which ranges from 0 to 1 , with higher values indicating a superior quality of government. Greater government quality is expected to result in fewer civil violence events.

Next, two measures of relative political performance are included. Both are drawn from the Relative Political Performance Data Set version 2.1 (Kugler and Tammen 2012). Relative political extraction approximates the ability of governments to appropriate portions of the national output to advance public goals. Relative political reach gauges the capacity of governments to mobilize populations under their control. Well-performing governments should correlate with less civil violence. That is, countries that score high on political extraction and political reach should be more successful at discouraging or thwarting civil violent events.

\section{Results}

A five-model sequence is used to investigate factors related to civil violence events in the MENA region during 1990-2004. All five equations include a standard set of control variables that serve as a base model throughout the analysis. Variables included in the base model are: (1) GDP per capita; (2) CPI; (3) population; (4) youth bulge; (5) ethnic group fractionalization; (6) regime type; (7) press freedom; and (8) ongoing civil war.

The first model includes a measure of oil and gas rents that does not distinguish ownership structure. The second model removes this measure and adds measures that distinguish oil and gas rents by ownership structure. One indicator corresponds to oil and gas rents that are primarily controlled by the state, and the other corresponds to oil and gas rents that are primarily privately controlled $^{3}$. The third model adds indicators of state-induced political terror and state sanctions. This equation tests the coercive capacity of countries. The fourth model removes the two indicators of state coercion and includes two measures that approximate the ability of a government to co-opt potential opposition. One measure gauges government consumption as a percentage of GDP, and the other looks at government spending on health and education. The final model addresses the argument that governments have the ability to reduce civil violence through cooperation. The two measures of government co-optation are removed and one measure of quality of governance and two measures of government effectiveness are added.

Table 1 shows the means, standard deviations, and minimum and maximum values for all the variables in the analysis. A correlation matrix of each model was run and a correlation above 0.6 was used as a point of concern. Using this threshold, the matrices demonstrate a few concerns regarding multicollinearity. However, separate VIF tests for each model indicate the absence of multicollinearity. The mean VIF scores for the first two models are below one, and only slightly above 2 for the third and fourth models. The mean VIF score for the fifth model is a bit higher at 3.87, but this is still not high enough to cause concern. A correlation matrix that includes all variables for all five models simultaneously is available in Appendix A. ${ }^{4}$

Table 2 presents the multivariate results of regressing civil violence events during 1990-2004 on the independent variables. Incidence rate ratios (IRRs) are shown to evaluate the relative effects of the controls. For IRRs, 1.0 is the base with values above 1.0 indicating a stronger positive effect and those below 1.0 a negative effect. IRRs indicate the expected rate of change for each additional one-unit increase in an independent variable (holding all other variables in the model constant).

Model 1 shows that the combined effect of oil and natural gas rents does not significantly affect civil violence events. GDP per capita has a slight positive effect on civil violence (IRR $=1.00, p<0.001$ ), as do population (IRR $=1.47, p<001$ ) and the youth bulge (IRR $=1.06, p<0.05)$. Ethnic fractionalization

3 In results not shown, I also tested publicly and privately controlled oil and gas rents in separate equations to guard against potential multicollinearity. The results are nearly identical. These results are available upon request.

4 It is important to note that not all of the variables in the correlation matrix are in an equation at the same time. Thus, some of the high correlations are not a concern. 
has a strong positive effect on civil violence events (IRR $=7.03, p<0.001)$. In fact, countries with higher degrees of ethnic fractionalization are seven times more likely to suffer from civil violence. Monarchies show significantly reduced civil violence events ( $\operatorname{IRR}=0.38, p<0.01$ ), and press freedom leads to more events $(\operatorname{IRR}=1.59, p<0.01)$.

Table 1. Descriptive Statistics of All Variables.

\begin{tabular}{lcccc}
\hline & Mean & Std. Dev. & Min. Value & Max. Value \\
\hline Civil Violence Events & 19.97 & 75.07 & 0 & 1125 \\
Oil and Gas Rents/GDP $(\log )$ & 2.17 & 1.51 & 0 & 4.03 \\
Public Oil and Gas Rents/GDP (log) & 2.00 & 1.58 & 0 & 4.03 \\
Private Oil and Gas Rents/GDP $(\log )$ & 0.27 & 0.86 & 0 & 3.74 \\
GDP per Capita & 6436.88 & 8173.51 & 257.65 & $34,176.98$ \\
CPI & 158.03 & 16.22 & 130.70 & 183.96 \\
Population $(\log )$ & 15.73 & 1.35 & 13.07 & 18.12 \\
Youth Bulge & 31.48 & 5.74 & 18.09 & 40.81 \\
Ethnic Fractionalization & 0.47 & 0.33 & 0 & 0.90 \\
Monarchy = & 0.44 & 0.50 & 0 & 1 \\
Press Freedom & 1.31 & 0.46 & 1 & 2 \\
Ongoing Civil War =1 & 0.09 & .28 & 0 & 1 \\
State Terror & 2.93 & 1.07 & 1 & 5 \\
State Sanctions & 4.08 & 5.93 & 0 & 53 \\
Government Consumption/GDP & 18.30 & 7.91 & 2.33 & 76.22 \\
Social Spending/GDP & 4.73 & 4.09 & 0 & 16.39 \\
Government Quality & 0.50 & 0.14 & 0.11 & 0.81 \\
Relative Political Extraction & 0.94 & 0.45 & 0.15 & 2.25 \\
Relative Political Reach & 0.91 & 0.11 & 0.67 & 1.16 \\
\hline
\end{tabular}

Model 2 removes the combined indicator of oil and gas rents in favor of two variables that capture ownership structure. An interesting finding emerges in this model-namely, oil and gas rents that are primarily controlled by the state have a negative effect on civil violence events ( $\operatorname{IRR}=0.78, p<0.05$ ), but privately controlled oil and gas rents show a non-significant result. This finding underscores the importance of taking ownership structure into account when looking at the effect of natural resources on conflict. Oher results remain largely the same from the first model. The same variables are significant, and the effects are in the same direction. There are, however, some changes in the strength of the effects.

Model 3 keeps the delineated measures of oil and gas rents and adds two measures of state coercive power. The effect of state-induced terror is positive and significant ( $\operatorname{IRR}=1.31, p<0.05$ ), as is the effect of state sanctions (IRR $=1.02, p<0.01$ ). The latter effect is not as strong, however. The positive effect of state controlled oil and gas rents remains present, suggesting that the effect cannot be explained through state violence or repression. There are some changes to the other effects, relative to the prior two models. The youth bulge, press freedom, and the monarchy dummy variable all lose significance in this model.

Model 4 removes the two variables approximating state coercion and adds two variables that gauge government co-optation. Government consumption as a percentage of GDP is positive and significant (IRR $=1.03, p<0.01$ ), though government spending on health and education is non-significant. Once more, state oil and gas rents demonstrate a negative relationship with civil violence events. Thus, state co-optation of opposition forces does not appear to explain this effect. Monarchies and press freedom, which lost significance in the prior model, once again demonstrate significant effects.

Model 5 tests the notion that governments can reduce violence through cooperation. The effect of relative political extraction is negative and significant $(\mathrm{OR}=0.57, p<0.05)$, as hypothesized. Quality of governance and relative political extraction are both non-significant. The effect of state controlled oil and gas rents remains negative and significant, again indicating that this effect cannot be explained by government's ability to foster cooperation with the citizenry. The remaining results are similar to those found in Model 4. 
Table 2. Negative Binomial Regression Analysis of Civil Violence Events in the MENA Region, 1990-2004.

\begin{tabular}{|c|c|c|c|c|c|c|c|c|c|c|}
\hline \multirow[b]{2}{*}{ Civil Violence Events } & \multicolumn{2}{|c|}{ Model 1} & \multicolumn{2}{|c|}{ Model 2} & \multicolumn{2}{|c|}{ Model 3} & \multicolumn{2}{|c|}{ Model 4} & \multicolumn{2}{|c|}{ Model 5} \\
\hline & IRR & Std. Err. & IRR & Std. Err. & IRR & Std. Err. & IRR & Std. Err. & IRR & Std. Err. \\
\hline Oil and Gas Rents/GDP $(\log )(t-1)$ & 0.89 & 0.07 & - & - & - & - & - & - & - & - \\
\hline Public Oil and Gas Rents/GDP (log) (t-1) & - & - & $0.78 *$ & 0.09 & $0.81 *$ & 0.09 & $0.75 *$ & 0.10 & $0.73^{* *}$ & 0.09 \\
\hline Private Oil and Gas Rents/GDP (log) (t-1) & - & - & 1.05 & 0.12 & 1.04 & 0.11 & 0.97 & 0.12 & 0.96 & 0.11 \\
\hline GDP per Capita $(\mathrm{t}-1)$ & $1.00^{* * *}$ & 0.00 & $1.00^{* * *}$ & 0.00 & $1.00^{* * *}$ & 0.00 & $1.00 * *$ & 0.00 & $1.00^{* *}$ & 0.00 \\
\hline $\mathrm{CPI}(\mathrm{t}-1)$ & 1.00 & 0.00 & 1.00 & 0.01 & 1.00 & 0.01 & 1.00 & 0.01 & 1.00 & 0.01 \\
\hline Population $(\log )(t-1)$ & $1.47^{* *}$ & 0.24 & $1.80^{* * *}$ & 0.30 & $1.58^{* *}$ & 0.27 & $1.79 * *$ & 0.37 & $1.53 *$ & 0.36 \\
\hline Youth Bulge $(\mathrm{t}-1)$ & $1.06^{*}$ & 0.03 & 1.06 * & 0.04 & 1.05 & 0.04 & 1.06 & 0.04 & 1.01 & 0.04 \\
\hline Monarchy $=1(\mathrm{t}-1)$ & $0.38^{* *}$ & 0.13 & $0.47 *$ & 0.19 & 0.64 & 0.26 & $0.29^{* *}$ & 0.15 & $0.43^{*}$ & 0.18 \\
\hline Press Freedom (t-1) & $1.59^{* *}$ & 0.31 & $1.48 *$ & 0.33 & 1.30 & 0.30 & $1.54 *$ & 0.37 & $1.45 *$ & 0.32 \\
\hline Ongoing Civil War = $1(\mathrm{t}-1)$ & 1.01 & 0.23 & 0.94 & 0.24 & 0.89 & 0.23 & 0.88 & 0.22 & 0.79 & 0.19 \\
\hline State Terror $(\mathrm{t}-1)$ & - & - & - & - & $1.31 *$ & 0.18 & - & - & - & - \\
\hline State Sanctions $(\mathrm{t}-1)$ & - & - & - & - & $1.02 * *$ & 0.01 & - & - & - & - \\
\hline Government Consumption/GDP (t-1) & - & - & - & - & - & - & $1.03 *$ & 0.02 & - & - \\
\hline Social Spending/GDP $(\mathrm{t}-1)$ & - & - & - & - & - & - & 0.99 & 0.02 & - & - \\
\hline Government Quality (t-1) & - & - & - & - & - & - & - & - & 0.35 & 0.33 \\
\hline Relative Political Extraction ( $\mathrm{t}-1$ ) & - & - & - & - & - & - & - & - & $0.57 *$ & 0.18 \\
\hline Wald $X^{2}$ & \multicolumn{2}{|c|}{40.66} & \multicolumn{2}{|c|}{45.94} & \multicolumn{2}{|c|}{66.95} & \multicolumn{2}{|c|}{43.47} & \multicolumn{2}{|c|}{54.61} \\
\hline Log Pseudolikelihood & \multicolumn{2}{|c|}{-623.67} & \multicolumn{2}{|c|}{-552.85} & \multicolumn{2}{|c|}{--547.73} & \multicolumn{2}{|c|}{-525.33} & \multicolumn{2}{|c|}{-532.33} \\
\hline $\mathrm{N}$ & \multicolumn{2}{|c|}{205} & \multicolumn{2}{|c|}{191} & \multicolumn{2}{|c|}{190} & \multicolumn{2}{|c|}{180} & \multicolumn{2}{|c|}{177} \\
\hline
\end{tabular}

${ }^{*} p<0.05 ;{ }^{* *} p<0.01 ; * * * p<0.001$ (two-tailed tests). 


\section{Discussion}

The Middle East is often considered the global "hotbed" of violence. Accounts for why vary, ranging from political, to economic, to cultural/religious explanations. I find that civil violence events in the MENA region from 1990 to 2004 were triggered by several factors examined in this analysis. Some of the strongest and most consistent drivers of violence were ethnic group fractionalization, population size, the existence of a free press, and monarchical regimes. The first two results are not surprising. Ethnic group fractionalization has been consistently found to stimulate conflict, and the MENA region has a long history of ethnic strife, particularly regarding Arab national movements. Moreover, the desire for an independent Kurdish state has resulted in longstanding conflict in Iraq, Turkey, and beyond, and Sudan has likewise been beset by ethnic conflict. The population effect might speak to stressors associated with rapid modernization, or it could simply reflect the likelihood that countries with more people are more prone to experience violent events. The positive effect of press freedom is somewhat unexpected, although it might signal that civil violence actors are more apt to engage in violence if they believe that their message will be broadcasted to a large audience. This effect is frequently found when examining acts of terrorism or other forms of political violence. Monarchical regimes, on the other hand, experienced significantly fewer civil violence events than non-monarchies. This result is expected, as monarchies are argued to have more institutional controls, relative to other regimes (Goldstone 2011). Barany (2012) suggests that monarchies have greater maneuvering power, can appeal to popular legitimacy, and are able to confront a divided opposition that is tribally organized.

The primary focus of this analysis, however, is on resource rents and their effect on civil violence. A large literature links resource dependency to the onset and duration of internal armed conflict. As the world's leading producer of oil, the MENA region is often thought to be particularly susceptible to the pitfalls of rent dependency. The paper focused on two research questions, asking if oil and gas rents, generally defined and measured, affect civil violence events, and, more specifically, if the ownership structure of the rent revenue mattered. Jones Luong and Weinthal (2010) point out that resource dependency is not conceptually the same as rentierism, at least not always. Rather, what matters is who controls the production and export of resources. Resource wealth that is controlled by the state is very different than resource wealth that is generated in the private market. State-control of resources can lead to bloated, autonomous governments, and the ensuing negative ramifications often associated with rentier states. They can also afford governments the ability to co-opt or suppress opposition. However, private control of resources concentrates wealth in the hands of the citizenry, not the elite. Thus, the effects of rentierism should be avoided.

This work lends support to the notion that ownerships structure matters. I find that the more general measure of oil and gas rents was not related to civil conflict; rather, delineating by ownership was key. To wit, my findings consistently show that publicly controlled oil and gas rents reduce civil violence, though privately controlled oil and gas rents are not significantly related to this outcome. These findings suggest oil and gas rents can facilitate a "rentier peace", and that an abundance of natural resources is not necessarily a curse. The non-effect of privately controlled oil and gas rents is not particularly surprising. If it is true, as is frequently theorized, that natural resources spur violence through breeding discontent, private corporations should be less likely to raise such ire, relative to state-owned enterprises. Generally, citizen grievances are directed at the ruling class since they are seen as beholden to the will of the citizenry in a way that private corporations are not. Privately-controlled rents are also unlikely to result in weak state institutions. To the contrary, as Weinthal and Luong (2006) point out, privately-held resource industries have an incentive to work with the state to foster robust institutions that will encourage market stability. Conversely, adherents of a rentier peace orientation commonly point to the state's ability to use resource rents to pacify would-be dissenters. While private corporations certainly have a stake in maintaining peace, it is unlikely that they will actively use rent revenue in its pursuit. It is even less likely that they would do so using coercion, as governess are able to do with resource rents. 
While the finding that publicly controlled oil and gas rents lead to less civil violence is interesting, a question of equal importance is how to interpret this finding. I find that the rent effect is not attenuated by state coercion, state co-optation or civilian cooperation. In fact, the negative effect of state controlled rents persists in spite of the positive effects that state terror, state sanctions, and government consumption have on civil violence, as well as the negative effect of relative political extraction of violent events. The robustness of the state oil effect therefore remains difficult to fully interpret. State capacity has been consistently linked to the onset (Arbetman and Kugler 1997; Fearon and Laitin 2003; Buhaug 2006), intensity (Benson and Kugler 1998; Lacina 2006), and duration (De Rouen and Sobek 2004) of armed conflict, and has been show to explain the linkage between natural resources and civil war (Humphreys 2005; Fearon 2005). This work does not echo these prior findings. I explore three key aspects of state capacity—a state's ability to control its population through coercion and deterrence (Herbst 2000; Tilly 2003), co-optation (Bueno de Mesquita et al. 2003), and cooperation (Fukuyama 2017; 2004; Levi 1988, 2006; North 1990; North et al. 2000); none of these factors, however, explain the link between publicly controlled resource rents and diminished civil violence events.

\section{Study Limitations}

There are a few limitations of this study that merit mention. One, common to all work on natural resources and conflict, is the possibility that oil and gas exports might be endogenous to the outcomes often attributed to natural resources. For instance, if conflict leads countries to discover more natural resources, or export resources more quickly, the causal nature of the relationship between resources and conflict becomes muddled. Ross (2015), however, notes that the opposite is generally true. That is, prior work has established that bad political conditions lead to less exploration and production of resources, not more. Even so, it is important to be aware of the potential for reversed causality when talking about natural resources and conflict. I lag all of the independent variables one year to address this issue, although doing so is only a partial solution. Additionally, the measure capturing on an ongoing civil war might partially mitigate this potential problem by serving as a proxy for existing internal instability.

An additional limitation is that the precise location of the civil violence events within countries is not known. Thus, it is unclear if they occurred in major metropolitan areas or more rural locales. Not knowing this information raises concerns that civil violence events in more remote areas are not being picked up by the media, and thus being excluded from the analysis.

Finally, the timeframe for this analysis is limited by data availability. I am only able to examine civil violence events from 1990 to 2004. Having a longer range-particularly more current data on civil violence-would be telling, especially given the violence associated with the Arab Awakening protests, as well as the ongoing civil war in Syria. There is no reason to believe that the results of this study are an artifact of a particular point in time, although it would be helpful to verify this with a longer time-series.

\section{Concluding Remarks}

This study contributes to the natural resource-conflict debate, but it also raises new questions. Most importantly, it adds further validity to the notion that natural resources cannot be treated monotonically by researchers. I find clear and robust evidence that, at least in the MENA region from 1990 to 2004, publicly controlled oil and gas rents reduce civil violence, whereas privately controlled rents do not have a significant effect. Unfortunately, this work is not able to pinpoint the precise nature of this relationship. Ultimately, indicators of state coercion, co-optation, and cooperation failed to attenuate the relationship between state controlled rents and civil violence. It is possible that this analysis did not accurately or fully capture state coercion, co-optation, and cooperation, and thus these forces might still be powerful mediating factors. It is also possible, however, that other factors not measured here better explain the apparent link between state controlled oil and gas rents and reduced civil violence in the MENA region. I therefore hope that future work continues to investigate this topic, 
paying specific attention to the nature of the relationship between conflict events and natural resource ownership structure.

Conflicts of Interest: The authors declare no conflict of interest.

\section{Appendix A}

Table A1. Correlation Matrix of All Independent Variables.

\begin{tabular}{|c|c|c|c|c|c|c|c|c|c|}
\hline & 1 & 2 & 3 & 4 & 5 & 6 & 7 & 8 & 9 \\
\hline Oil and Gas Rents/GDP (log) (1) & 1 & & & & & & & & \\
\hline Public Oil and Gas Rents/GDP (log) (2) & 0.77 & 1 & & & & & & & \\
\hline Private Oil and Gas Rents/GDP (log) (3) & 0.15 & -0.52 & 1 & & & & & & \\
\hline GDP per Capita (4) & 0.38 & 0.49 & -0.24 & 1 & & & & & \\
\hline CPI (5) & 0.14 & 0.07 & 0.07 & 0.23 & 1 & & & & \\
\hline Population (log) (6) & -0.19 & -0.26 & 0.15 & -0.55 & 0.02 & 1 & & & \\
\hline Youth Bulge (7) & -0.20 & -0.42 & 0.38 & -0.72 & -0.14 & 0.29 & 1 & & \\
\hline Ethnic Fractionalization (8) & -0.18 & -0.30 & 0.22 & -0.05 & 0.01 & 0.24 & 0.03 & 1 & \\
\hline Monarchy (9) & -0.18 & 0.03 & -0.29 & 0.49 & 0.04 & -0.47 & -0.43 & 0.30 & 1 \\
\hline Press Freedom (10) & -0.43 & -0.25 & -0.18 & 0.03 & -0.29 & -0.08 & -0.19 & 0.26 & 0.35 \\
\hline Ongoing Civil War (11) & -0.02 & -0.12 & 0.17 & -0.20 & 0.00 & 0.29 & 0.22 & 0.19 & -0.30 \\
\hline State Terror (12) & 0.00 & -0.10 & 0.16 & -0.43 & -0.07 & 0.63 & 0.35 & 0.15 & -0.65 \\
\hline State Sanctions (13) & -0.09 & -0.06 & -0.02 & -0.14 & 0.02 & 0.37 & -0.01 & 0.16 & -0.08 \\
\hline Government Consumption/GDP (14) & 0.16 & 0.27 & -0.19 & 0.24 & -0.17 & -0.54 & -0.28 & 0.08 & 0.55 \\
\hline Social Spending/GDP (15) & -0.08 & -0.01 & -0.09 & 0.02 & 0.45 & -0.05 & -0.18 & -0.01 & 0.21 \\
\hline Government Quality (16) & -0.16 & 0.13 & -0.41 & 0.28 & -0.13 & -0.41 & -0.34 & -0.20 & 0.53 \\
\hline Relative Political Extraction (17) & -0.23 & 0.09 & -0.44 & 0.20 & -0.15 & -0.37 & -0.45 & 0.06 & 0.60 \\
\hline Relative Political Reach (18) & 0.39 & 0.58 & -0.38 & 0.76 & 0.06 & -0.76 & -0.51 & -0.03 & 0.54 \\
\hline
\end{tabular}

Table A2. Correlation Matrix of All Independent Variables (continued).

\begin{tabular}{llllllllll}
\hline & 10 & 11 & 12 & 13 & 14 & 15 & 16 & 17 & 18 \\
Press Freedom (10) & 1 & & & & & & & & \\
Ongoing Civil War (11) & -0.07 & 1 & & & & & & & \\
State Terror (12) & -0.20 & 0.63 & 1 & & & & & \\
State Sanctions (13) & 0.27 & 0.03 & 0.28 & 1 & & & & \\
Government Consumption/GDP (14) & 0.11 & -0.27 & -0.34 & -0.09 & 1 & & & \\
Social Spending/GDP (15) & -0.05 & -0.22 & -0.26 & -0.05 & 0.11 & 1 & & & \\
Government Quality (16) & 0.31 & -0.53 & -0.71 & -0.23 & 0.28 & 0.26 & 1 & & \\
Relative Political Extraction (17) & 0.47 & -0.41 & -0.63 & -0.14 & 0.31 & 0.27 & 0.68 & 1 & \\
Relative Political Reach (18) & 0.09 & -0.27 & -0.54 & -0.32 & 0.49 & 0.02 & 0.44 & 0.37 & 1 \\
\hline
\end{tabular}

\section{References}

Andersen, Jørgen J., and Michael Ross. 2012. The Big Oil Change: A Closer Look at the Haber-Menaldo Analysis. Unpublished Manuscript. Available online: http:/ / www.sscnet.ucla.edu/polisci/faculty/ross/The\%20Big\% 200il\%20Change\%20-\%20APSA\%20version.pdf (accessed on 15 December 2017).

Anderson, Lisa. 1987. The state in the Middle East and North Africa. Comparative Politics 20: 1-18. [CrossRef] Arbetman, Marina, and Jacek Kugler, eds. 1997. Political Capacity and Economic Behavior. Doulder: Westview Press. Auty, Richard M., ed. 2001. Resource Abundance and Economic Development. New York: Oxford University Press.

Azam, Jean-Paul. 1995. How to pay for the peace? A theoretical framework with references to African countries. Public Choice 83: 173-84. [CrossRef]

Azam, Jean-Paul. 2001. Civil war and the social contract. Public Choice 115: 455-75. [CrossRef]

Bakaki, Zorzeta. 2016. Fossil Fuel Rents: Who Initiates International Crises? Peace Economics, Peace Science and Public Policy 22: 173-90. [CrossRef]

Barany, Zoltan D. 2012. The Soldier and the Changing State: Building Democratic Armies in Africa, Asia, Europe, and the Americas. Princeton: Princeton University Press. 
Barma, Naazneen, Kai Kaiser, and Tuan Minh Le, eds. 2012. Rents to Riches?: The Political Economy of Natural Resource-Led Development. Washington, DC, USA: World Bank Publications.

Basedau, Matthias, and Jann Lay. 2009. Resource Curse or Rentier Peace? The Ambiguous Effects of Oil Wealth and Oil Dependence on Violent Conflict. Journal of Peace Research 46: 757-76. [CrossRef]

Beblawi, Hazem, and Giacomo Luciani. 1987. The Rentier State. Nation, State and Integration in the Arab World. London: Croom Helm, Volume 2, p. 89.

Bellin, Eva. 2002. The Robustness of Authoritarianism in the Middle East: A Comparative Perspective. Paper presented at the Annual Meeting of the American Political Science Association, New York, NY, USA, 2002.

Benson, Michelle, and Jacek Kugler. 1998. Power parity, democracy, and the severity of internal violence. Journal of Conflict Resolution 42: 196-209. [CrossRef]

Boulding, K. 1989. The Three Faces of Power. Newbury Park: Sage.

Brunnschweiler, Christa N., and Erwin H. Bulte. 2008. The resource curse revisited and revised: A tale of paradoxes and red herrings. Journal of Environmental Economics and Management 55: 248-64. [CrossRef]

Brunnschweiler, Christa N., and Erwin H. Bulte. 2009. Natural resources and violent conflict: Resource abundance, dependence, and the onset of civil wars. Oxford Economic Papers 61: 651-74. [CrossRef]

Bueno de Mesquita, Bruce, Alastair Smith, Randolph M. Siverson, and James D. Morrow. 2003. The Logic of Political Survival. Cambridge, MA, USA, London, UK: MIT Press.

Buhaug, Halvard. 2006. Relative capability and rebel objective in civil war. Journal of Peace Research 43: 691-708. [CrossRef]

Cameron, Colin, and Pravin Trivedi. 1998. Models for Count Data. Cambridge: Cambridge University Press.

Cederman, Lars Erik, Andreas Wimmer, and Brian Min. 2010. Why do Ethnic Groups Rebel? New Data and Analysis. World Politics 62: 87-119. [CrossRef]

Center for Energy Economics. 2008. A Citizen's Guide to National Oil Companies: A Technical Report. Washington: World Bank Group and Center for Energy Economics, University of Texas.

Chaudhry, Kiren Aziz. 1989. The price of wealth: Business and state in labor remittance and oil economies. International Organization 43: 101-45. [CrossRef]

Chaudhry, Kiren Aziz. 1997. The Price of Wealth: Economies and Institutions in the Middle East. Ithaca: Cornell University Press.

Collier, Paul, and Anke Hoeffler. 1998. On Economic Causes of Civil War. Oxford Economic Papers 50. Oxford: Oxford University Press, pp. 563-73.

Collier, Paul, and Anke Hoefflery. 2004. Greed and Grievance in Civil War. Oxford Economic Papers 56. Oxford: Oxford University Press, pp. 563-95.

Collier, Paul, Anke Hoeffler, and Dominic Rohner. 2009. Beyond Greed and Grievance: Feasibility and Civil War. Oxford Economic Papers 61. Oxford: Oxford University Press, pp. 1-27.

Costello, Matthew. 2017. Oil Ownership and Domestic Terrorism. In Non-State Violent Actors and Social Movement Organizations: Influence, Adaptation, and Change. Bingley: Emerald Publishing Limited, pp. 107-36.

Costello, Matthew, J. Craig Jenkins, and Hassan Aly. 2015. Bread, justice, or opportunity? The determinants of the Arab awakening protests. World Development 67: 90-100. [CrossRef]

Cotet, Anca M., and Kevin K. Tsui. 2013. Oil and Conflict: What Does the Cross Country Evidence Really Show? American Economic Journal: Macroeconomics 5: 49-80. [CrossRef]

Dal Bó, Ernesto, and Pedro Dal Bó. 2011. Workers, warriors, and criminals: Social conflict in general equilibrium. Journal of the European Economic Association 9: 646-77. [CrossRef]

Davenport, Christian, and Patrick Ball. 2002. Views to a Kill: Exploring the Implications of Source Selection in the Case of Guatemalan State Terror, 1977-1996. Journal of Conflict Resolution 26: 427-50. [CrossRef]

De Rouen, Karl R., Jr., and David Sobek. 2004. The dynamics of civil war duration and outcome. Journal of Peace Research 41: 303-20. [CrossRef]

De Soysa, Indra. 2002. Paradise is a bazaar? Greed, creed, and governance in civil war, 1989-99. Journal of Peace Research 39: 395-416. [CrossRef]

Drukker, David M. 2003. Testing for serial correlation in linear panel-data models. Stata Journal 3: 168-77.

Fearon, James. 2005. Primary Commodity Exports and Civil War. Journal of Conflict Resolution 49: 483-507. [CrossRef]

Fearon, James, and David Laitin. 2003. Ethnicity, Insurgency and Civil War. American Political Science Review 97: 75-90. [CrossRef] 
Fjelde, Hanne. 2009. Buying peace? Oil wealth, corruption, and civil war, 1985-99. Journal of Peace Research 46: 199-218. [CrossRef]

Fjelde, Hanne, and Indra De Soysa. 2009. Coercion, Co-optation, or Cooperation? State Capacity and the Risk of Civil War, 1961-2004. Conflict Management and Peace Science 26: 5-25. [CrossRef]

Freedom House. 2013. Freedom in the World. New York: Freedom House, Available online: www.feedomhouse. org/report-types / freedom-world (accessed on 2 March 2016).

Friedman, Thomas. 2006. The First Law of Petropolitics. Foreign Policy 154: 28-36.

Fukuyama, Francis. 2017. State Building: Governance and World Order in the 21st Century. New York: Cornell University Press.

Fukuyama, Francis. 2004. The imperative of state-building. Journal of democracy 15: 17-31. [CrossRef]

Gandhi, Jennifer, and Adam Przeworski. 2006. Cooperation, cooptation, and rebellion under dictatorships. Economics and Politics 18: 1-26. [CrossRef]

Gleditsch, Nils Petter, Peter Wallensteen, Mikael Eriksson, Margareta Sollenberg, and Håvard Strand. 2002. Armed conflict 1946-2001: A new dataset. Journal of peace research 39: 615-637. [CrossRef]

Goldstone, Jack A. 2011. Understanding the revolutions of 2011. Foreign Affairs 90: 8-16.

Guriev, Sergei, Anton Kolotilin, and Konstantin Sonin. 2011. Determinants of Nationalization in the Oil Sector: A Theory and Evidence from Panel Data. The Journal of Law, Economics and Organization 27: 301-23. [CrossRef]

Hegre, Håvard, and Nicholas Sambanis. 2006. Sensitivity analysis of empirical results on civil war onset. Journal of Conflict Resolution 50: 508-35. [CrossRef]

Herbst, Jeffrey. 2000. Economic incentives, natural resources and conflict in Africa. Journal of African Economies 9: 270-94. [CrossRef]

Heydemann, Steven. 2004. Networks of Privilege: The Politics of Economic Reform in the Middle East. New York: Palgrave-St. Martin's Press.

Humphreys, Macartan. 2005. Natural Resources, Conflict, and Conflict Resolution. Journal of Conflict Resolution 49: 508-37. [CrossRef]

Isham, Jonathan, Lant Pritchett, Michael Woolcock, and Gwen Busby. 2003. The Varieties of the Resource Experience: How Natural Resource Export Structures Affect the Political Economy of Economic Growth. Washington DC: World Bank Kaplan, D. \& R. Kaplinsky. 1999. Trade and industrial policy on an uneven playing field: The case of the deciduous fruit canning industry in South Africa'. World Development 27: $1787-1801$.

Jenkins, J. Craig, Katherine Meyer, Matthew Costello, and Hassan Aly. 2011. International Rentierism in the Middle East Africa, 1971-2008. International Area Studies Review 14: 3-31. [CrossRef]

Jenkins, J. Craig, Charles Lewis Taylor, Marianne Abbott, Thomas V. Maher, and Lindsey Peterson. 2012. The World Handbook of Political Indicators IV. Columbus: Mershon Center for International Security Studies, The Ohio State University, Available online: https:/ / sociology.osu.edu/worldhandbook (accessed on 9 October 2017).

Johnston, Jack, and John Dinardo. 1997. Econometric Methods, 4th ed. New York: McGraw-Hill Companies, Inc., pp. 204-326.

Jones Luong, Pauline, and Erika Weinthal. 2010. Oil Is Not a Curse: Ownership Structure and Institutions in Soviet Successor States. New York: Cambridge University Press.

Karl, Terry Lynne. 1997. The Paradox of Plenty: Oil Booms and Petro States. Berkeley: University of California Press.

Koubi, Vally, Gabriele Spilker, Tobias Böhmelt, and Thomas Bernauer. 2014. Do natural resources matter for interstate and intrastate armed conflict? Journal of Peace Research 51: 227-43. [CrossRef]

Kugler, Jacek, and Ronald Tammen. 2012. Performance of Nations. Lanham: Rowman and Littlefield.

Lacina, Bethany. 2006. Explaining the severity of civil wars. Journal of Conflict Resolution 50: 276-89. [CrossRef]

Land, Kenneth C., Patricia McCall, and Daniel S. Nagin. 1996. A Comparison of Poisson, Negative Binomial, and Semi-Parametric Mixed Poisson Regression Models with Empirical Applications to Criminal Careers Data. Sociological Methods and Research 24: 387-440. [CrossRef]

Le Billon, Philippe. 2001. Angola's Political Economy of War: The Role of Oil and Diamonds, 1975-2000. African Affairs 100: 55-80. [CrossRef]

Le Billon, Philippe. 2005. Corruption, reconstruction and oil governance in Iraq. Third World Quarterly 26: 685-703. [CrossRef]

Le Billon, Philippe, and Fouad El Kathib. 2004. From Free Oil to "Freedom Oil": Terrorism, War and US Geopolitics in the Persian Gulf. Geopolitics 9: 109-37. [CrossRef] 
Levi, Margaret. 1988. Of Rule and Revenue. Berkley: University of California Press.

Levi, Margaret. 2006. Why we need a new theory of government. Perspectives on Politics 4: 5-19. [CrossRef]

Luciani, Giacomo. 1987. Allocation vs. Production State. In The Rentier State. Edited by Hazem Beblawi and Giacomo Luciani. London: Croom Helm.

Lujala, Paivi. 2009. Deadly Combat over Natural Resources: Gems, Petroleum, Drugs and the Severity of Armed Civil Conflict. Journal of Conflict Resolution 53: 50-71. [CrossRef]

Lujala, Paivi. 2010. The spoils of nature: Armed civil conflict and rebel access to natural resources. Journal of Peace Research 47: 15-28. [CrossRef]

Mahdavi, Paasha. 2011. State Ownership and the Resource Curse: A New Dataset on Nationalizations in the Oil Industry. Available online: http:/ / ssrn.com/abstract=1916590 (accessed on 22 February 2016).

Mahdavy, Hossein. 1970. The patterns and problems of economic development in rentier states: The case of Iran. Life 1000.

McPherson, Charles. 2003. National Oil Companies: Evolution, Issues, Outlook. Washington: Oil, Gas and Chemicals Group, World Bank. Available online: http://siteresources.worldbank.org/INTOGMC/ Resources/NOCPaperMcPherson.pdf (accessed on 8 July 2012).

Mommer, Bernard. 2002. Global Oil and the Nation State. New York: Oxford University Press.

North, Douglass C. 1990. Institutions, Institutional Change, and Economic Performance. London: Cambridge University Press.

North, Douglass C., William Summerhill, and Barry R. Weingast. 2000. Order, disorder, and economic change: Latin America versus North America. In Governing for Prosperity. Edited by Bruce Bueno de Mesquita and Hilton Root. New Haven: Yale University Press.

Olson, Mancur. 2000. Power and Prosperity: Outgrowing Communist and Capitalist Dictatorship. New York: Basic Books.

Ross, Michael. 2001. Does oil hinder democracy? World Politics 53: 325-61. [CrossRef]

Ross, Michael. 2003. Oil, drugs, and diamonds: How do natural resources vary in their impact on civil war. In The Political Economy of Armed Conflict: Beyond Greed and Grievance. Boulder: Lynne Rennier Publishers, pp. 47-67.

Ross, Michael. 2004. What Do We Know About Natural Resources and Civil War? Journal of Peace Research 41: 337-56. [CrossRef]

Ross, Michael. 2015. What Have We Learned About the Resource Curse? Annual Review of Political Science 18: 239-259. [CrossRef]

Ross, Michael. 2006. A Closer Look at Oil, Diamonds and Civil War. Annual Review of Political Science 9: $265-300$. [CrossRef]

Ross, Michael. 2012. The Oil Curse: How Petroleum Wealth Shapes the Development of Nations. Princeton: Princeton University Press.

Smith, Benjamin. 2004. Oil Wealth and Regime Survival in the Developing World, 1960-1999. American Journal of Political Science 48: 232-46. [CrossRef]

Sorens, Jason. 2011. Mineral production, territory, and ethnic rebellion: The role of rebel constituencies. Journal of Peace Research 48: 571-85. [CrossRef]

Teorell, Jan, Nicholas Charron, Marcus Samanni, Soren Holmberg, and Bo Rothstein. 2011. The Quality of Government Dataset. Göteborg: The Quality of Government Institute University of Göteborg.

The Economist. 2005. The Curse of Oil: Special Report, the Paradox of Plenty. London: Economist Group.

Thies, Cameron G. 2007. The Political Economy of State Building in Sub-Saharan Africa. The Journal of Politics 69: 716-31. [CrossRef]

Thies, Cameron. 2010. Of Rulers, Rebels, and Revenue: State Capacity, Civil War Onset, and Primary Commodities. Journal of Peace Research 47: 321-32. [CrossRef]

Tilly, Charles. 2003. The Politics of Collective Violence. Cambridge: Cambridge University Press.

Tordo, Silvana. 2011. National Oil Companies and Value Creation. Washington, DC, USA: World Bank Publications. Tordo, Silvana, and Brandon S. Tracy. 2012. National Oil Companies and Value Creation. Washington: World Bank.

United Nations Population Division. 2012. The World Population Prospects. 2012 Revision. New York, NY, USA. Available online: http:/ / esa.un.org/wpp/ (accessed on 12 December 2017).

Warshaw, Christopher. 2012. The Political Economy of Expropriation and Privatization of the Oil Sector. In Oil and Governance: State-Owned Enterprises and the World Energy Supply. Edited by David G. Victor, David R. Hults and Mark G. Huber. New York: Cambridge University Press, pp. 35-61.

Wegenast, Tim. 2016. Oil, Natural Gas, and Intrastate Conflict: Does Ownership Matter? International Interactions 42: 31-55. [CrossRef] 
Weinthal, Erika, and Pauline Jones Luong. 2006. Rethinking the Resource Curse: Ownership Structure, Institutional Capacity, and Domestic Constraints. Annual Review of Political Science 9: 241-63.

Wood, Reed M., and Mark Gibney. 2010. The Political Terror Scale (PTS): A Re-introduction and a Comparison to CIRI. Human Rights Quarterly 32: 367-400. [CrossRef]

World Bank. 2008. A Citizens Guide to National Oil Companies, Part B, Data Director. Houston: Center for Energy Economics, University of Texas-Austin.

World Bank. 2015. World Development Indicators; Washington: World Bank. Available online: http://data. worldbank.org/data-catalog/world-development-indicators (accessed on 15 December 2017). 